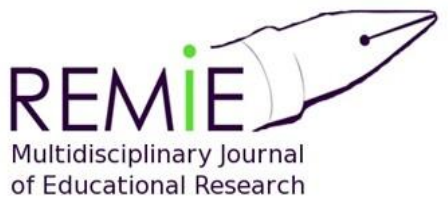

Hipatia Press

www.hipatiapress.com

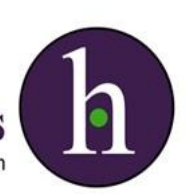

Instructions for authors, subscriptions and further details:

http://remie.hipatiapress.com

\title{
List of Reviewers
}

Date of publication: February $15^{\text {th }}, 2019$

Edition period: February 2019 - June 2019

To cite this article: REMIE Editors. (2019). List of Reviewers.

Multidisciplinary Journal of Educational Research, 9(1), doi:

10.17583/remie.2019.4084

To link this article: http://dx.doi.org/10.17583/remie.2019.4084

\section{PLEASE SCROLL DOWN FOR ARTICLE}

The terms and conditions of use are related to the Open Journal System and to Creative Commons Attribution License (CC-BY). 
REMIE - Multidisciplinary Journal of Educational Research, Vol. 9 No. 1 February 2019

\section{List of Reviewers}

Thank you to 2018 reviewers. On behalf of the Multidisciplinary Journal of Educational Research we deeply appreciate reviewers' contributions to the quality of this journal. The journal owes this debt with those who have been peer reviewers during this period. Yours sincerely,

Esther Rocca

Roseli R. de Mello

Editors
Alguacil-Jimenez, Mario
Lopez Aguileta, Garazi
Alvarez Cifuentes, Pilar
Bachega, Denise
Lluch, Pau
Braga, Fabiana Marini
Marigo, Adriana
Molina, Silvia
Calzolari-Neto, Anselmo
Moreira, Raquel
Cantó Alonso, José
Morlá, Teresa
Castro, Marcos
Chisvert, Maria José
Nascente, Renata
Natividad, Laura
Constantino, Francisca L.
Parra Camacho, David
Craciun, Daniela
Diez-Palomar, Javier
Peña Axt, Juan Carlos
Felicetti, Vera
Prezenszky, Bruno Cortegozo
Reyes, Claudia
Girbés Peco, Sandra
Hofling, Camila
Rodríguez Oramas, Alfonso
Jovani, Maria
Sisla, Heloísa
Still, Chantae
Laborda Máñez, José
Tellado, Itxaso
León Jiménez, Suzana
Lima, Emília Freitas de
Villarejo, Bea
Villarreal Fernández, Jorge

2019 Hipatia Press

ISSN: 2014-2862

DOI: $10.17583 /$ remie. 2019.4084 